\title{
Diagnosis of Cystic Fibrosis in Premature Infants
}

\author{
ASHLEY KING, R. F. MUELLER, A. F. HEELEY, AND N. R. C. ROBERTON \\ Department of Histopathology [A.K.], Department of Genetic Counselling [R.F.M.], and Department of Pediatrics \\ [N.R.C.R.], Addenbrooke's Hospital, Cambridge; and Regional Biochemical Genetic Screening Laboratory \\ [A.F.H.], Peterborough District Hospital, Peterborough, England
}

\begin{abstract}
Meconium ileus and pancreatic changes, as described in cystic fibrosis, were found, at autopsy, in a series of six infants who received prolonged neonatal intensive care for prematurity. Cystic fibrosis had not been suspected clinically. These pathological findings are so frequent in sick premature infants, amounting to $12 \%$ of all neonatal autopsies conducted over a period of 2 yr in our unit, that we question their specificity for cystic fibrosis and suggest they may be a manifestation of disordered physiology in the severely ill neonate. (Pediatr Res 20: 536-541, 1986)
\end{abstract}

\section{Abbreviations}

CF, cystic fibrosis

IRT, serum immunoreactive trypsin

NICU, neonatal intensive care unit

The diagnosis of $\mathrm{CF}$ in the neonatal period in the absence of a sweat test result is based on the post mortem findings of meconium ileus and pancreatic changes (1). These pathological findings have been described chiefly in infants dying from the complications of meconium ileus. The specificity of these changes has not been seriously questioned although there are sporadic clinical reports of meconium ileus occurring in the absence of CF (2-9). In none of these case reports is there an adequate description of the pathology of the bowel or pancreas.

A series of six premature infants is reported, born over a 2-yr period, in whom meconium ileus and/or pancreatic changes were found at postmortem. None of these infants had any other clinical features suggesting meconium ileus attributable to $\mathrm{CF}$. In view of the frequency with which a previously unsuspected diagnosis of $\mathrm{CF}$ was made at postmortem over the 2-yr period and the similarity of the clinical course in these infants, the specificity of the pathological changes for establishing the diagnosis of $\mathrm{CF}$ in the neonate is questioned. This diagnostic dilemma has obvious implications for recurrence risk counselling.

In addition, IRT estimations were carried out retrospectively on serum samples from these infants and the results are discussed.

\section{PATIENTS}

We report six infants admitted to the NICU at Cambridge Maternity Hospital between June 1982 and August 1984, whose clinical details are given in Table 1.

Received August 25, 1985; accepted February 3, 1986.

Address for correspondence and reprint requests Dr. Ashley King, Department of Histopathology, Addenbrooke's Hospital, Hills Road, Cambridge, CB2 2QQ, England.

R.F.M. is in receipt of an MRC Training Fellowship.

\section{RESULTS}

At autopsy infants 1,2, and 3 had the classical gross and microscopic picture of meconium ileus with evidence of perforation and subsequent peritonitis (Table 2). The ileum was progressively dilated along its length and contained greenishgray, tenacious meconium with a collapsed, empty colon (Fig. 1). The entire intestine was dilated in infants 5 and 6 . Both small and large bowel were normal in case 4 and no sections were taken. Histological changes in all infants examined were similar showing intestinal villi distorted by inspissated secretions and distension of glands by intensely staining eosinophilic mucus (Fig. 2).

The pancreas in infants 4 and 6 showed widespread dilatation of acini and ductules with focal acinar atrophy and early fibrosis (Fig. 3). The changes in infants 1 and 2 were less marked, with widespread dilatation of ductules containing inspissated secretions but no atrophy or fibrosis. Case 3 showed focal ductular dilatation only, and the pancreas in infant 5 was normal.

The salivary glands in infants 1,2 , and 3 showed dilatation of ductules with inspissated secretions. The salivary glands were normal in the other three infants.

The lungs in all infants showed bronchopulmonary dysplasia. Dilatation of submucosal tracheal glands was seen in infants 2 , 3,5 , and 6 . There was no evidence of lung infection in any infant.

The liver in all infants showed widespread cholestasis. Bile duct proliferation and mild periportal inflammation was also seen in infants $1,2,4$, and 6 . The liver in infant 5 showed extensive hemorrhagic infarction similar to the changes described in Echo 11 infection $(10,11)$. Focal biliary cirrhosis was not seen in any infant. A routine section of the epididymis in infants 1 , 2 , and 6 was normal.

Estimates of immune reactive trypsin in serum obtained from these infants in the neonatal period were carried out (Table 3 ). The IRT values in infants 3 and 4 were clearly elevated. The values for infants 1,2 , and 6 were well within the normal range. The first sample obtained from infant 5 on day 8 was normal but subsequently became transiently elevated just prior to death.

\section{DISCUSSION}

Comparison of pathological findings in $C F$ with those observed in six patients. In the presence of suggestive clinical features the diagnosis of $\mathrm{CF}$ at all ages is confirmed by the sweat test. At postmortem these patients show a combination of distinctive pathological changes in the small bowel, pancreas, liver, and respiratory tract (1).

Bowel. In about $10 \%$ of patients with $\mathrm{CF}$, the disease manifests itself in the neonatal period with the clinical picture of meconium ileus. These infants usually develop signs of intestinal obstruction within the first $24-48 \mathrm{~h}$ of life due to failure to pass the viscous meconium beyond the terminal ileum. The small bowel is pro- 
Table 1. Clinical features of six premature infants with postmortem diagnosis of CF*

\begin{tabular}{|c|c|c|c|c|c|c|}
\hline Infant & Maternal details & Sex & $\begin{array}{l}\text { Gestation } \\
\text { (wk) }\end{array}$ & $\begin{array}{l}\text { Birth wt } \\
(\mathrm{kg})\end{array}$ & $\begin{array}{c}\text { Age at death } \\
\text { (days) }\end{array}$ & RDS \\
\hline 1 & $\mathrm{G}_{2} \mathrm{P}_{1} 22 \mathrm{yr}$ & $\mathrm{M}($ twin $\mathrm{II})$ & 29 & 1.2 & 24 & $\begin{array}{c}+ \\
\text { IPPV, } 95 \% \mathrm{O}_{2} \\
30 \% \mathrm{O}_{2} \text { in headbox on day } 17\end{array}$ \\
\hline 2 & $\mathrm{G}_{4} \mathrm{P}_{1} 31 \mathrm{yr}$ & $\mathrm{M}$ & 26 & 0.96 & 35 & $\begin{array}{l}+ \\
\text { IPPV, } 80 \% \mathrm{O}_{2} \\
\text { CPAP day } 7\end{array}$ \\
\hline 3 & $\mathrm{G}_{3} \mathrm{P}_{0} 43 \mathrm{yr}$ & $\mathrm{F}$ & 25 & 0.7 & 18 & $\begin{array}{l}\stackrel{+}{\text { IPPV }, 70 \% ~} \mathrm{O}_{2} \text { throughout } \\
\text { life }\end{array}$ \\
\hline 4 & $\mathrm{G}_{4} \mathrm{P}_{3} 26 \mathrm{yr}$ & M & 34 & 2.95 & 10 & - \\
\hline 5 & $\mathrm{G}_{2} \mathrm{P}_{0} 19 \mathrm{yr}$ & $\mathrm{F}$ & 31 & 1.98 & 11 & $\begin{array}{c}+ \\
\text { IPPV, } 60 \% \mathrm{O}_{2} \\
25 \% \mathrm{O}_{2} \text { in headbox day } 3\end{array}$ \\
\hline 6 & $\mathrm{G}_{2} \mathrm{P}_{0} 32 \mathrm{yr}$ & $\mathrm{M}($ twin II $)$ & 29 & 0.569 & 52 & $\begin{array}{l}\qquad \pm \\
\text { IPPV day } 2 \text { only, reventi- } \\
\text { lated for septicemia }\end{array}$ \\
\hline
\end{tabular}

* RDS, respiratory distress syndrome; IPPV, intermittent positive pressure ventilation; CPAP, continuous positive airways pressure.

Table 2. Clinical course of six premature infants with postmortem diagnosis of $C F^{*}$

\begin{tabular}{|c|c|c|c|c|c|c|c|c|}
\hline Infant & $\begin{array}{c}\text { Passed } \\
\text { meconium } \\
\text { (days) }\end{array}$ & PN & Hypotension & $\begin{array}{c}\text { Renal } \\
\text { impairment }\end{array}$ & PDA & IVH & Infection & GIT complications \\
\hline 1 & $\begin{array}{l}2 \\
\text { Rarely } \\
\text { thereafter }\end{array}$ & + & $\begin{array}{l}\quad- \\
\text { Rx Dopamine } \\
\text { and plasma ex- } \\
\text { panders }\end{array}$ & + & - & $\begin{array}{l}\stackrel{+}{\text { Grade III- }} \\
\text { IV }\end{array}$ & - & $\begin{array}{l}\text { Never tolerated feeds, } \\
\text { abdominal distension; } \\
\text { gastrografin enema } \\
\text { showed normal colon, } \\
\text { obstruction in termi- } \\
\text { nal ileum; twin I died } \\
24 \text { h, Enterobacter } \\
\text { cloacae sepsis }\end{array}$ \\
\hline 2 & $\begin{array}{l}1,2,3 \\
\text { Rarely } \\
\text { thereafter }\end{array}$ & + & + & + & + & - & $\begin{array}{l}\text { Serratia septi- } \\
\text { cemia, day } 5 \\
\text { Candida peri- } \\
\text { tonitis }\end{array}$ & $\begin{array}{l}\text { Never tolerated feeds, } \\
\text { abdominal distension; } \\
\text { x-ray showed NEC } \\
\text { and perforation; man- } \\
\text { aged conservatively }\end{array}$ \\
\hline 3 & $\begin{array}{l}1,2,15 \\
\text { only }\end{array}$ & + & + & + & $\begin{array}{l}++ \\
\text { Recur- } \\
\text { ring }\end{array}$ & $\begin{array}{l}\stackrel{+}{\text { Grade III- }} \\
\text { IV }\end{array}$ & Fungal peritonitis & $\begin{array}{l}\text { Feeds poorly tolerated, } \\
\text { abdominal distension; } \\
\text { x-ray showed perfora- } \\
\text { tion no NEC }\end{array}$ \\
\hline 4 & $\begin{array}{c}4 \\
\text { and daily } \\
\text { thereafter }\end{array}$ & - & + & + & - & - & $\begin{array}{c}\text { Escherichia coli } \\
\text { Meningitis }\end{array}$ & $\begin{array}{l}\text { Feeds not tolerated; } \\
\text { bile-stained aspirates }\end{array}$ \\
\hline 5 & $\begin{array}{l}3 \\
\text { and daily } \\
\text { thereafter }\end{array}$ & - & + & + & - & - & $\begin{array}{l}\text { ECHO } 7 \text { septi- } \\
\text { cemia, day } 4\end{array}$ & $\begin{array}{l}\text { Abdominal distension, } \\
\text { DIC }\end{array}$ \\
\hline 6 & 3 & + & + & + & - & - & $\begin{array}{r}\text { Klebsiella septi- } \\
\text { cemia, day } 23\end{array}$ & $\begin{array}{l}\text { Always tolerated feeding } \\
\text { poorly, abdominal } \\
\text { distension, hepato- } \\
\text { splenomegaly, ascites, } \\
\text { generalized pancyto- } \\
\text { penia; twin II, } 1.344 \\
\mathrm{~kg} \text {, mild RDS, thrived }\end{array}$ \\
\hline
\end{tabular}

* PN, parenteral nutrition; PDA, patent ductus arteriosus; IVH, intraventricular hemorrhage; GIT, gastrointestinal tract; NEC, necrotizing enterocolitis; DIC, disseminated intravascular coagulation; RDS, respiratory distress syndrome. 
gressively dilated along its length and is filled with tenacious meconium, the colon being hypoplastic and empty. Histologically the glands of the small intestine are distended with inspissated eosinophilic secretions. The abnormally viscous mucous

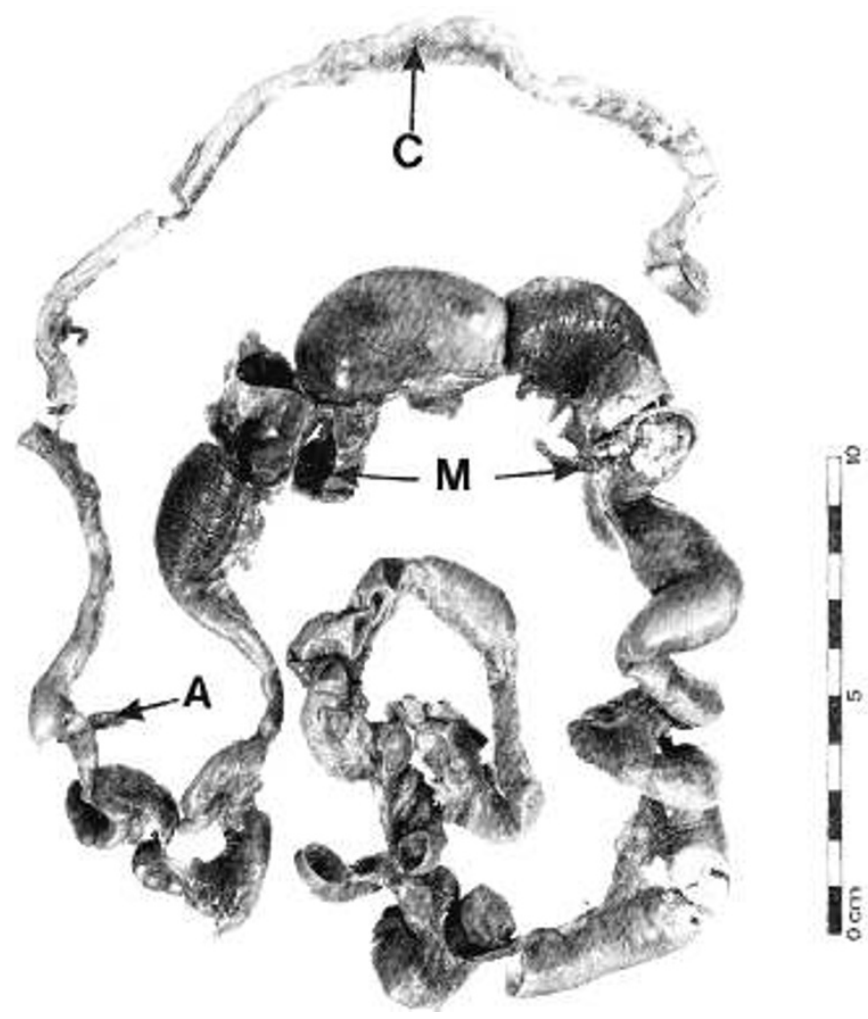

Fig. 1. Ileum and colon of infant 1 showing progressive dilatation of the small intestine which is maximal in the midileum. The lumen is filled with tenacious meconium $(M)$. The colon $(C)$ is collapsed and empty. The appendix is marked $A$. secretions in exocrine glands throughout the body lead to cystic dilatation of ducts and fibrous atrophy of glands. In these infants significant changes are rarely found in the liver and respiratory tract.

In this series infants 1,2 , and 3 were on gross examination pathologically indistinguishable from this classical picture whereas infants 5 and 6 showed generalized dilatation of the bowel. The histopathological changes in the bowel of infants 1 , $2,3,5$, and 6 were those said to be typical of CF. No sections of bowel were taken in infant 4 .

Pancreas. The pancreatic changes in infants with $\mathrm{CF}$ who die in the neonatal period vary widely and may be normal. Focal dilatation of acini and ductules is the earliest change progressing to widespread involvement of the glands with flattening of the epithelium and plugging of ductules and acini by inspissated secretions. Acinar atrophy and periductal and interacinar fibrosis are evidence of severe involvement (1).

Focal dilatation of ducts may be seen in dehydration and uremia but more generalized or severe changes are considered diagnostic of CF (1). Four of our infants showed widespread acinar dilatation and two of these (cases 4 and 6) also showed early atrophy and fibrosis. Considering these widely accepted criteria, four of our infants showed characteristic changes of $\mathrm{CF}$ in the pancreas.

Similar histological changes to those found in the pancreas may be seen in the salivary glands (1); mild changes were seen in infants 1,2 , and 3 .

Liver. The characteristic hepatic involvement in CF is focal biliary cirrhosis (14). This was not seen in any of the infants in this series. Although the hepatic abnormalities of cholestasis, periportal inflammation, and bile duct proliferation seen in the infants in this series have been described in infants with $C F$ dying in the neonatal period; they certainly are not specific for this condition. Such changes have been attributed to other factors including parenteral feeding and sepsis (14).

Respiratory tract. The only change reported in the respiratory tract in babies with CF dying in the neonatal period is hyperplasia and obstruction with mucus of bronchial and tracheal submucosal glands (1). Similar changes were seen in infants $2,3,5$, and

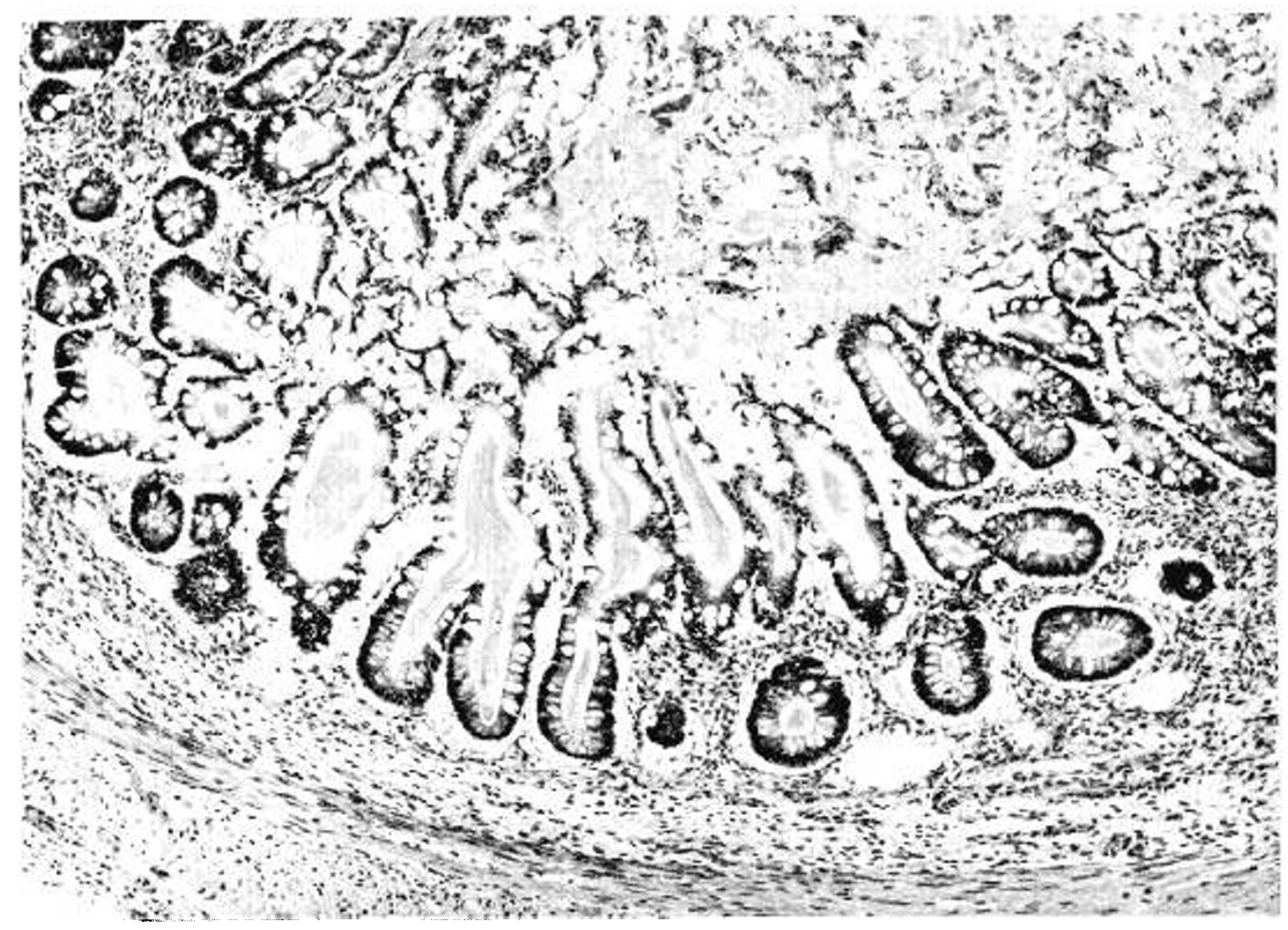

Fig. 2. Section of ileum of infant 2 showing distortion of villi by inspissated secretions and distension of mucous glands $(\times 64)$. 


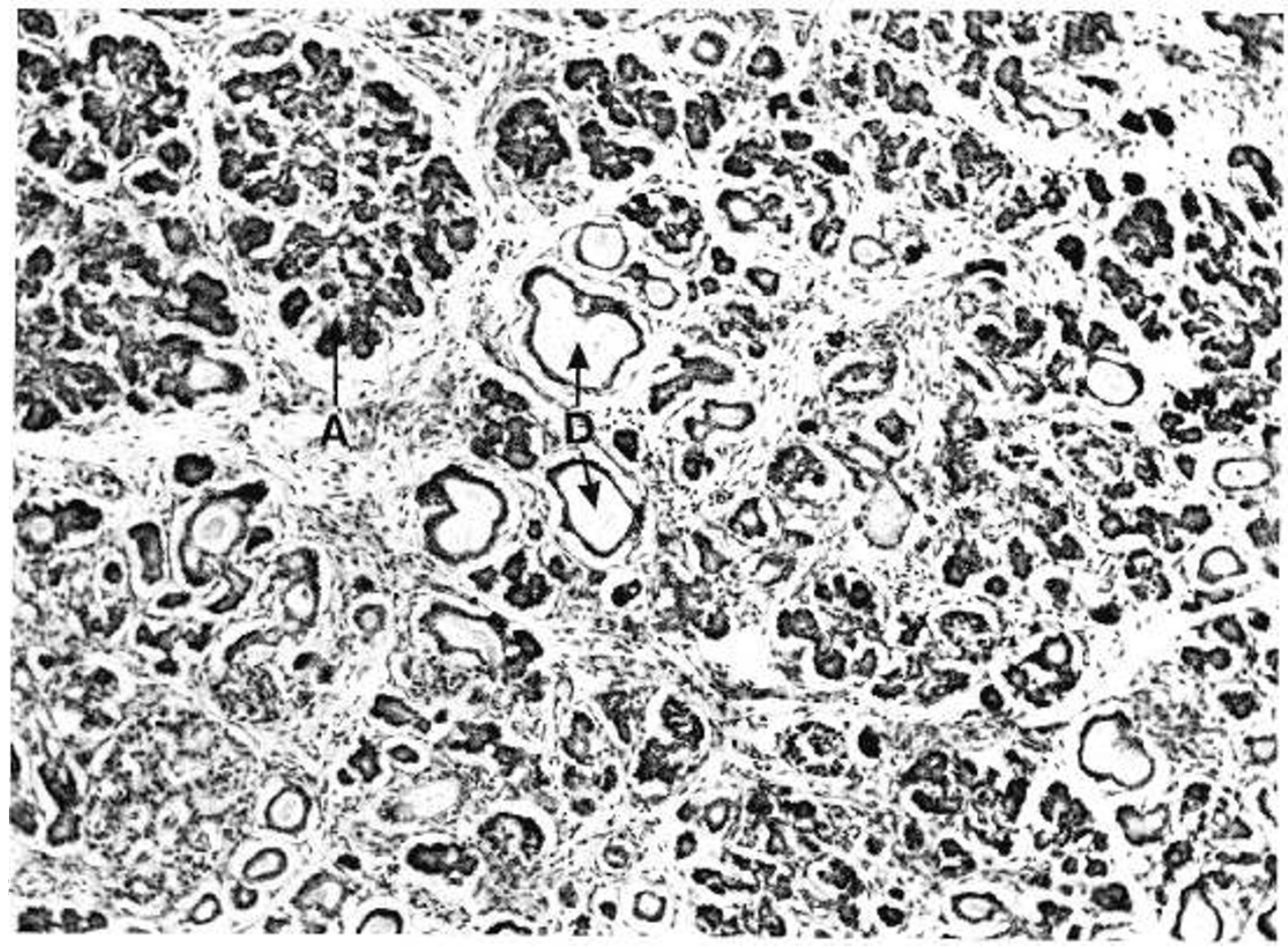

Fig. 3. Section of pancreas of infant 6 showing widespread dilatation of ductules $(D)$ and acini by inspissated secretions with early fibrosis and atrophy. A normal acinus is marked $A$.

6 in this series. However, all the infants in the present series had been on mechanical ventilation and any changes observed may be secondary to this. Some authors believe that in CF the changes in the mucus glands occur secondarily to lung infection and that mucus hypersecretion is not the primary event facilitating infection (15). Moreover the specificity of the respiratory tract changes for CF have been disputed by morphometric studies (15-17).

Reasons for questioning diagnosis of $C F$. It is possible that these infants all have $\mathrm{CF}$, and we may be observing a previously unreported predisposition to prematurity in CF. A recent report suggests that the intestinal problems in premature infants with $\mathrm{CF}$ might be clinically overshadowed by the respiratory and neurological problems (19).

However, we do not believe that these infants have CF for the following reasons.

1) All the infants in the present series were born over a period of $2 \mathrm{yr}$. This is equivalent to a prevalence of one per 100 infants admitted to the NICU. It might be argued that an apparently increased prevalence might result from the Cambridge NICU being a regional centre, but this is unlikely as the primary reason for referral of these infants was their prematurity. In addition, the incidence of CF in the area served by the Cambridge NICU over the same period without the addition of the infants in this series is already one in 2000 .

2) Although limited in number, none of the siblings in the families of these infants have CF. In addition, there was no evidence at postmortem of findings suggestive of $\mathrm{CF}$ in the deceased twin of infant 1 , and the live twin of infant 6 is developing normally and has no symptoms suggestive of $\mathrm{CF}$. Both the twin pairs were of the same sex but it is not known whether they were identical or not.

3) There was a discrepancy between the clinical picture seen in these infants and that which occurs with classical meconium ileus. Although meconium was passed normally in the first few days of life, stools were passed infrequently later in the neonatal period when abdominal distension developed. Despite this clinical discrepancy the pathological findings in the ileum and pan- creas were similar to those described in CF. It is possible that the pathological findings in the gastrointestinal tract in infants with the inspissated meconium syndrome, had they been examined, might have been those of classical meconium ileus.

4) All the infants were premature and had in common similar, severe neonatal complications requiring intensive care. Respiratory distress syndrome, intraventricular hemorrhage, uremia, and overwhelming sepsis were seen in the majority of the infants. In addition all these infants developed abdominal distension and tolerated oral feeding poorly requiring parenteral nutrition in four infants.

Possible pathophysiological explanations for postmortem findings. All the pathological changes in CF are due to blockage of ducts by concentrated, inspissated secretions $(18,20)$. If the secretions in the ileum and pancreas become concentrated for other reasons, pathological changes similar to those seen in $\mathrm{CF}$ might be expected. This could reflect the general policy of the Cambridge NICU with regard to strict limitation of fluid replacement in neonates combined with the lack of enteral feeding and uraemia.

Another possibility is that these infants could have one of the variants of meconium ileus occurring in the absence of CF (29 ), although others have questioned the existence of such an entity $(1,12)$. This condition has been referred to by a variety of names; inspissated meconium syndrome, ileal meconium plugs, meconium blockage syndrome, and meconium disease. This syndrome is said to be clinically distinguishable from true meconium ileus seen in association with $\mathrm{CF}$ in that the infants generally develop obstructive symptoms after the $1 \mathrm{st}$ wk of life having passed meconium initially. There is no adequate description of the pathology of the ileum in these reports. In addition, in several of the reports an association with prematurity, low birth weight, and respiratory distress syndrome has been noted $(3,5,8)$. The pathogenesis of this ill-defined entity is obscure, but there may be some overlap with the transient functional ileus seen in premature infants with respiratory distress $(6,8,13)$.

The infants in this series show many clinical similarities with 
Table 3. Postmortem findings in six infants diagnosed with $C F^{*}$

\begin{tabular}{|c|c|c|c|c|c|c|}
\hline Infant & Gut $\dagger$ & Pancreas $\$$ & $\begin{array}{c}\text { Salivary } \\
\text { gland } \neq\end{array}$ & Liver & Lung & Other systems \\
\hline 1 & $\begin{array}{l}\quad+ \\
\text { Previous } \\
\text { perfora- } \\
\text { tion, mi- } \\
\text { crocolon }\end{array}$ & $2 / 3$ & 2 & $\begin{array}{l}\text { Cholestasis, } \\
\text { focal bile } \\
\text { duct prolif- } \\
\text { eration }\end{array}$ & $\mathrm{BPD}$ & IVH \\
\hline 2 & $\begin{array}{l}\quad+ \\
\text { Perforated } \\
\text { microco- } \\
\text { lon }\end{array}$ & 2 & 1 & $\begin{array}{l}\text { Focal bile } \\
\text { duct prolif- } \\
\text { eration }\end{array}$ & $\begin{array}{l}\text { Submucous glands } \\
\text { dilated }\end{array}$ & $\begin{array}{l}\text { Subendocardial infarcts, splenic } \\
\text { infarcts, small cerebellar sub- } \\
\text { arachnoid hemorrhage }\end{array}$ \\
\hline 3 & $\begin{array}{l}\quad+ \\
\text { Jejunal } \\
\text { perfora- } \\
\text { tion, peri- } \\
\text { tonitis }\end{array}$ & 1 & 2 & Cholestasis & BPD & $\begin{array}{l}\text { Subendocardial infarcts, adrenal } \\
\text { hemorrhage, focal renal hem- } \\
\text { orrhages, recent IVH, Can- } \\
\text { dida }\end{array}$ \\
\hline 4 & $\begin{array}{l}\text { No sec- } \\
\text { tions avail- } \\
\text { able }\end{array}$ & 3 & 0 & $\begin{array}{l}\text { Cholestasis, } \\
\text { pseudoacini } \\
\text { formation, } \\
\text { bile duct } \\
\text { prolifera- } \\
\text { tion }\end{array}$ & $\mathrm{BPD}$ & $\begin{array}{l}\text { Subendocardial infarcts, recent } \\
\text { hemorrhages, IVH, cerebellar } \\
\text { hemorrhage, meningitis }\end{array}$ \\
\hline 5 & $\begin{array}{l}\stackrel{+}{\text { Mild dila- }} \\
\text { tion }\end{array}$ & 0 & 0 & $\begin{array}{r}\text { Hemorrhage, } \\
\text { cholestasis }\end{array}$ & $\begin{array}{l}\text { Hyaline membrane } \\
\text { disease }\end{array}$ & $\begin{array}{l}\text { Massive hemorrhage into adre- } \\
\text { nals, kidneys, liver, and } \\
\text { brain; microthrombi suben- } \\
\text { docardial infarcts ECHO } 7\end{array}$ \\
\hline 6 & $\stackrel{+}{\text { Dilation }}$ & 3 & 0 & $\begin{array}{l}\text { EMH, bile } \\
\text { duct prolif- } \\
\text { eration, } \\
\text { cholestasis }\end{array}$ & $\mathrm{BPD}$ & $\begin{array}{l}\text { Brain infarcted, Klebsiella } \\
\text { grown at PM }\end{array}$ \\
\hline
\end{tabular}

* BPD, bronchopulmonary dysplasia; IVH, intraventricular hemorrhage; EMH, extramedullary hemopoiesis.

$\dagger+$, dilated bowel filled with intensely staining meconium with inspissated secretions in glands.

$\ddagger 0$, normal; 1 , focal dilatation of ducts with inspissated secretions; 2 , diffuse dilatation of ducts and atrophy; 3 , dilatation of ducts with atrophy and fibrosis of gland.

Table 4. IRT levels from serum obtained from six infants with a postmortem diagnosis of $\mathrm{CF}^{*} \uparrow$

\begin{tabular}{cc} 
& $\begin{array}{c}\text { Serum IRT (day taken) } \\
\text { (ng/ml) }\end{array}$ \\
\hline Infant & 39 \\
2 Twin I & 36 \\
2 & $\$ 18,16,17(5)$ \\
Twin II & $18,29(7)$ \\
& $>400(10)$ \\
3 & $\$>400,>400(5)$ \\
4 & $>400(7)$ \\
& $400(8)$ \\
& $179(9)$ \\
5 & $27(9)$ \\
& $\$ 237,151(11)$ \\
6 & $24(6)$ \\
& $39(10)$ \\
& $23(34)$ \\
\hline
\end{tabular}

* IRT, immunoreactive trypsin.

$\dagger$ The reference range for serum IRT values was determined on 58 premature infants in whom the diagnosis of CF did not subsequently arise. The distribution of observed values was not normal and the $98 \%$ confidence limits were obtained by $\log$ transformation was $15-117 \mathrm{ng} /$ $\mathrm{ml}$, mean $42 \mathrm{ng} / \mathrm{ml}$.

$\ddagger$ Separate samples taken on the same day. the case reports of inspissated meconium syndrome in that all the infants were premature and most had respiratory distress syndrome. In addition unlike infants with meconium ileus due to $C F$ the infants in this series initially passed normal meconium and gastrointestinal symptoms only developed after the first few days of life.

Value of immunoreactive trypsin estimations. The recent availability of IRT estimations might be the means of differentiating which, if any, of these infants have CF. The range of IRT levels for samples collected during the 2 nd wk of life from infants in a special care unit is the same as that for normal term infants (21). Dehydration and renal failure can artifactually raise IRT levels. The elevated levels in infants 3 and 4 support the diagnosis of CF. However, because the population of premature infants routinely screened as yet is small, identification of a premature infant with an elevated IRT level in whom the diagnosis of $\mathrm{CF}$ is been subsequently confirmed by a sweat test, will be a relatively rare event. The IRT levels in infants 1,2 , and 6 suggest that these infants are normal, but the false-negative rate of IRT estimations in premature infants is not known. Of note however, is the fact that in the reported series of IRT neonatal screening, none of the infants who subsequently turned out to have $\mathrm{CF}$, despite normal neonatal IRT values (true false negatives), were born prematurely. The pattern of IRT values seen in infant 5 is similar to that observed in idiopathic hypertrypsinaemia of infancy and has also been observed in one infant in association with a perinatal cytomegalovirus infection (Heeley AF, personal 
observation). Until more is known about factors that might affect IRT values in premature infants the IRT results in these infants can neither confirm or exclude the diagnosis of CF.

Diagnostic dilemma. Initially on the basis of the histological findings in these patients, their parents were counselled that they were at risk of producing an infant with $\mathrm{CF}$ in subsequent pregnancies. As our experience unfolded, it became apparent that the histological changes reported herein are not specific for $\mathrm{CF}$ and that in the absence of other clinical features or a positive family history, such counselling was unjustified.

Until there is a reliable means of diagnosing CF in this group of infants, the diagnosis of CF should not be made solely on the basis of gut and pancreatic postmortem findings alone in premature infants who have endured an extremely complex and prolonged neonatal illness.

Acknowledgment. The authors acknowledge the assistance of the technical staff of Addenbrooke's Histology Laboratory for the sections and to Chris Burton in producing the illustrations for this manuscript.

\section{REFERENCES}

1. Oppenheimer EH, Esterly JR 1975 Pathology of cystic fibrosis. Review of the literature and comparison with 146 autopsied cases. Perspect Pediatr Pathol 241:278

2. Rickham PP, Boeckman CR 1965 Neonatal meconium obstruction in the absence of mucoviscidosis. Am J Surg 109:173-177

3. Siegel MJ, Shackleford GD, McAlister WH 1979 Neonatal meconium blockage in the ileum and proximal colon. Pediatr Radiol 132:79-82

4. Mikity VG, Hodgman JE, Paciulli J 1967 Meconium blockage syndrome Radiology 88:740-744

5. Shigemoto H, Endo S, Isomoto T, Sano K, Taguchi K 1978 Neonatal meconium obstruction in the ileum without mucoviscidosis. J Pediatr Surg
13:475-479

6. Olsen MM, Luck SR, Lloyd-Still J, Raffensperger JG 1982 The spectrum of meconium disease in infancy. $\mathbf{J}$ Pediatr Surg 17:479-481

7. Talwalker VC, Kittur DH 1980 Ileal meconium plugs. Arch Dis Child 55:288 291

8. Vinograd I, Mogle P, Peleg O, Alpan G, Lernau OZ 1981 Meconium disease in premature infants with very low birth weight. J Pediatr 103:963-966

9. Barguno JM, Figueras J, Botet F, Morales L, Jimenez R 1983 Obstruccion intestinal por meconio en un prematuro sin mucoviscidosis. An Esp Pediatr 19:335-336

10. Wreghitt TG, Gandy GM, King A, Sutehall G 1984 Fatal neonatal echo 7 virus infection. Lancet $2: 465$

11. Berry PJ, Nagington J 1982 Fatal infection with echovirus 11. Arch Dis Child 57:22-29

12. Antonowicz I, Schwachman H 1979 Meconium in health and disease. Adv Paediatr 26:275-310

13. Dunn PM 1963 Intestinal obstruction in the newborn with special reference to transient functional ileus associatd with respiratory distress syndrome. Arch Dis Child 38:459-467

14. Oppenheimer EH, Esterley JR 1975 Hepatic changes in young infants with cystic fibrosis: Possible relation to focal biliary cirrhosis. J Pediatr $86: 683$ 689

15. Chow CW, Landau LI, Taussig LM 1982 Bronchial mucous glands in the newborn with cystic fibrosis. Eur J Paediatr 139:240-243

16. Sturgess J, Imrie J 1982 Quantitative evaluation of the development of tracheal submucosal glands in infants with cystic fibrosis and control infants. Am J Pathol 106:303-311

17. Oppenheimer EH 1981 Similarity of the tracheobronchial mucous glands and epithelium in infants with and without CF. Hum Pathol 12:36-48

18. di Sant-Agnese PA, Talamo RC 1967 Pathogenesis and pathophysiology of cystic fibrosis of the pancreas: fibrocystic disease of the pancreas (mucoviscidosis). N Engl J Med 277:1287-1295, 1344-1352, 1399-1408

19. Barson AJ 1984 Incidence of meconium ileus. Lancet $2: 472$

20. Kopelman H, Durie P, Gaskin K, Weizman Z, Forstner G 1985 Pancreatic fluid secretion and protein hyperconcentration in cystic fibrosis. $N$ Engl $J$ Med 312:329-334

21. Heeley AF, Heeley ME, Richmond SWJ 1983 The value of blood trypsin measurement by RIA in the early diagnosis of cystic fibrosis. In: Albertin A, PG Crosignani PG (eds) Progress in Perinatal Medicine. Excerpta Medica, Oxford, pp 95-203 